\title{
Natural products: an extraordinary source of value-added compounds from diverse biomasses in Brazil
}

Viviane Cândida da Silva ${ }^{1}$ and Clenilson Martins Rodrigues ${ }^{2^{*}}$

\begin{abstract}
The biodiversity of Brazil contains an extraordinary number of compounds from natural products with a wide and complex variety of molecular structures, therefore representing an economic potential in biomasses to be explored. Plant systems are the principal source of medicine and directly contribute to the development of new drugs in addition to agrochemicals, cosmetics, fine chemicals and nutraceuticals. Besides plants, other biomasses can be used as raw material, including marine organisms and microorganisms such as extremophilic and endophytic microbes. Interest in natural products for diverse uses is attributed to their different bioactivities, low toxicity and environmental sustainability. Based on these attributes, other non-biological applications of natural products from biomasses have been reported for use in textiles, antifouling coating in marine transportation, wood adhesives, industrial polymers and biofuel. After extractions of natural products of pharmaceutical interest or industrial application, such as polymers, or even of metabolites for biofuels, the residues (e.g., fibers) or other compounds (e.g., nutrients) are discarded generating unnecessary environmental pollution, but they could be used for the production of different value-added products. Some examples of residues that are being explored for added value by extracting other natural metabolites are olive and apple pomace, macauba and carnauba cakes, and cashew nut shell liquid. Residues and by-products derived from different biomasses in Brazil are a potential source of compounds of biological and industrial interest and therefore must be investigated in order to add value to the entire supply chain of natural product.
\end{abstract}

Keywords: Natural products; Biomass; By-products; Residues; Value-added compounds; Bioactivity; Industrial application

\section{Introduction}

Brazil has an amazing diversity in living species - plants, animals and microorganisms - due to its great territorial extension and combination of different biomes, such as the Cerrado, Atlantic forest, and Amazon rainforest [1].

Since early human history, natural products - compounds produced by plants, animals, or microorganisms - have been studied and utilized for the treatment of diseases. Plants are the principal source of medicine and directly contribute to the development of new drugs in addition to agrochemicals, cosmetics and food [2]. For example, tubocurarine, isolated from a plant in Brazil, has been used for many years as a muscle relaxant during the preoperative period and is a model for the production of similar medicines [3].

\footnotetext{
* Correspondence: clenilson.rodrigues@embrapa.br

Embrapa Agroenergy - Parque Estação Biológica (PqEB), s/no, W3 Norte, 70770-901 Brasília, DF, Brazil

Full list of author information is available at the end of the article
}

Interest in the use of natural products has increased significantly in comparison to synthetic compounds [4], and now, other non-biological applications are being studied [5-9].

One of the most recent examples is in textile applications, which include plant-based products such as fibers, polysaccharides, dyes, oils, and other compounds with antibiotic activity. Biodegradable polysaccharides are used as thickeners, carrying dyestuffs, chemicals, and other printing assistants to textile substrates during the printing process. Prolonged contact between the body and the textile is responsible for microbial infections, which has contributed to the use of oxidizing agents, halogens, and metal-based complexes, for example, to prevent microbial growth. To minimize the environmental risks associated with those synthetic agents, researchers are currently looking for natural dyes with antimicrobial activities that adhere to the textile substrates. Besides the growing market 
demand for textiles that offer comfort, other properties are gaining prominence such as deodorizing, insect-repellent, flame retardant, and UV protective properties [4].

After extraction of natural products of pharmaceutical interest or industrial application, the residues (e.g., fibers [10]) or other compounds (e.g., nutrients [8]) are discarded, not only generating an environmental pollution problem, but a loss of biomass that could have been used for the production of different products with economic value [11].

There is growing interest in the discovery of natural products for use in sunscreens and the option of new active filters with the capability of ultraviolet light absorption. The liquid extracted from cashew nut shells (CNSL) - 19,000 tons exported from the Brazilian northeast in 2007 - is sometimes wasted by industry and could be used as an ingredient in sunscreens after chemical transformations [12].

Considering the diversity of plants, animals, and microorganisms, the possibility of obtaining compounds of biological or industrial interest, residues and by-products derived from various biomasses must be continuously investigated in order to add value to natural products and thus avoid future problems of environmental impact.

\section{Review}

Brazil's biodiversity is well-known, containing about 15\% of the world's living species, among plants, animals, and microorganisms, and much more yet to be discovered before extinction. There are more than 45,000 described plant species - $18 \%$ of the world's total flora. Several species important for the world economy - including peanuts, Brazil nuts, carnauba wax, rubber, guarana, pineapples and cashews, in addition to numerous species, forage, fruit, seed oils, medicines and timber, among others - originate from Brazil, that also contains $10 \%$ of the world's fauna, including vertebrates and invertebrates [1].

Historically, natural products have been very important for Brazil: coffee, sugarcane and soy are some examples that have been important to the social-economic development of the country. The cultivation of sugarcane can be considered the first economic activity of great relevance in the country and it has become prominent in the global scenario [13].

The country comprises different and important biomes, such as the savannah area (Cerrado), the Amazonian rainforest and the Atlantic tropical forest. It is a rich and biologically diverse on three levels (genetic, species, and ecosystem), the product of large climate variability and geomorphology of a country of continental dimensions. This diversity results in an extraordinary number of compounds of natural products with a wide and complex variety of molecular structures and represents an economic potential in biomass to be explored [3].

\section{Natural products and biological applications}

Since early human history, natural products have been investigated and utilized for the treatment of diseases. The large number of chemical structures is the result of combinatorial chemistry of nature, which besides generating stereochemically complex structures with many functional groups, produce compounds that specifically interact with biological targets, and are used as templates for drug discovery [2]. In the global pharmaceutical market, estimated at 300 billion dollars, about $40 \%$ is derived directly or indirectly from pharmaceutical products of natural sources (of which $75 \%$ from plants and $25 \%$ from animals and microorganisms) [13].

Despite the great biodiversity in Brazil, few examples of natural compounds arising from this biological wealth have led to the development of new drugs. Tubocurarine (Figure 1), a poisonous alkaloid isolated from Chondodendron tomentosum, has been used for many years for muscle relaxation during the preoperative period and is a prototype for the synthesis of analogues. A mixture of phenolic compounds present in a standardized extract of Stryphnodendron adstringens is another example of a Brazilian herbal medicine [3]. Studies on the piperidine alkaloids isolated from Senna spectabilis identified compounds [(-)-3-O-acetylspectaline and iso-6-spectaline (Figure 1)] that exhibited DNA-damaging activity [14].

Besides plants, other biomass organisms could be sources of compounds in drug discovery. The world's oceans, covering more than $70 \%$ of the Earth's surface, represent a rich source of bioactive compounds, many of which belong to novel chemical classes not found in terrestrial sources. An example of marine-derivative anticancer drug is halichondrin B (Figure 1), isolated from a sponge, and bryostatin 1 (Figure 1), a macrolide isolated from a bryozoan [2]. Brazil has considerable possibilities for search in this field due to its wide coastal area.

Another representative Brazilian discovery is the peptide bradykinin (Figure 1), isolated from venom of the viper Bathrops jararaca, which has been the model for the synthesis of structural analogues of hypertension regulators [3].

Some distinct and potential sources have been explored through the development of new isolation, identification, and analytical techniques of unexplored microscopic species and their metabolites, like endophytic, extremophilic, and marine microbes [2]. An example of bioactive compounds found in endophytic microbe, present in tissues of living plant cells, is the polyketide citrinin (Figure 1) isolated from the endophytic fungus Penicillium janthinellum, and from the fruit of Melia azedarach (Meliaceae), a plant collected in Brazil, which inhibited $100 \%$ of Leishmania mexicana at a concentration of $40 \mu \mathrm{g} / \mathrm{mL}[15]$. 
<smiles>COc1cc2c(c(Oc3ccc(CC4c5cc(Oc6cccc(O)c6)ccc5CCN4C)cc3)c1O)[C@H](C)N(C)CC2</smiles>

Tubocurarine

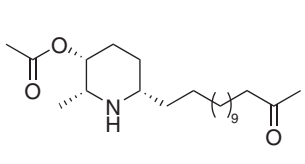

(-)-3-O-acetylspectaline<smiles>CC(=O)CNCCC1CCC(O)[C@H](C)N1</smiles>

iso-6-spectaline

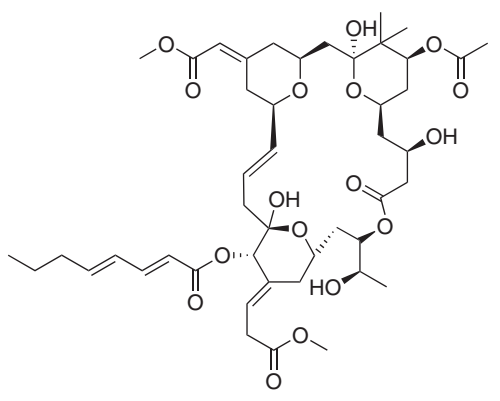

Bryostatin 1

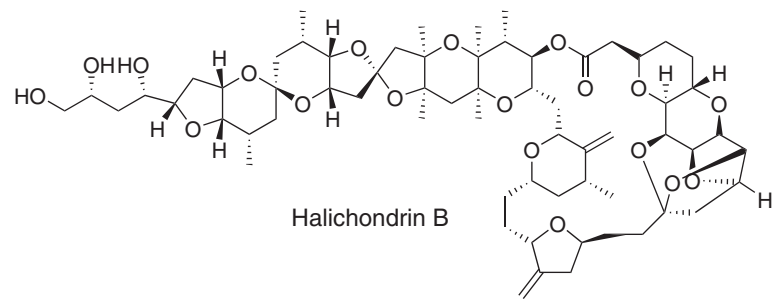<smiles>N=C(N)NCCCC(N)C(=O)N[C@@H](Cc1ccccc1)C(=O)N[C@H]1CCCN1C(=O)C(CO)NC(=O)[C@H](Cc1ccccc1)NC(=O)CNC(=O)[C@@H]1CCCN1C(=O)[C@@H]1CCCN1C(=O)[C@H](N)CCCNC(=N)N</smiles><smiles>CC1OC=C2C(=CC(=O)C(C(=O)O)=C2O)C1C</smiles>
Citrinin

Figure 1 Compounds with bioactivity isolated from different natural products.

There are several research groups that focus on exploring the rich biodiversity in Brazil, looking for bioactive compounds from plants of the Cerrado, the Atlantic forest and plant endophytic fungi, where it is possible to find botanical, chemical, pharmacological, and toxicological compound information in their database [16].

\section{Natural products and non-biological applications}

Nowadays, interest in the use of natural products has increased significantly, and the reason for this trend is the idea of safety in comparison to synthetic compounds as they are understood by the general public, attributed to several scientific studies reporting different bioactivities of natural products, abundant availability, biocompatibility, low toxicity, and environmental responsibility [4]. Thus, other non-biological applications have been reported for natural product biomass.

One of the most recent example is in textile applications. Besides the growing market demand for textiles that offer comfort, other properties, such as deodorizing, insect-repellent, flame retardant, UV protective as well as antimicrobial activity, are gaining prominence. The plant-based products used are fibers, polysaccharides, dyes and pigments, oils, and other bioactive compounds.
Some by-products from commodity crops such as sugarcane straw and stalk, banana and pineapple leaves and others, have been investigated in order to develop new cellulose fibers [4].

Another application for natural products is for antifouling coating in marine transportation. The undesirable accumulation of marine organisms on ship hulls can lead to increased fuel consumption to simply maintain cruising speed in addition to metallic corrosion, blockage of pipes and filtration systems, etc. An alternative is the use of the natural product, tannin, as biocide that, besides being produced by different plants as part of their defense system against pathogenic agents, is non-toxic to the ecosystem of the ocean. Tannin extracts are coagulated with metallic cations and last for 12 months under immersion [5]. Tannins play an important role in textile finishing too, as well as in the preservation of leather, and as a dye agent [4].

More examples of non-biological applications of natural products include their employment in wood adhesives. Because of limited reserves of oil, price variability, and dangers to the environment and human health, some new products have been proposed for use, among them tannins, carbohydrates, unsaturated oils, rice bran and 
soybean proteins [6], lignin in the straw of other herbaceous crops [17] and vegetable oils [18]. This can later be modified to exhibit several types of functionalities $[18,19]$, such as condensation polymerization, and acquiring polymers such as polyurethanes, polyesters and polyethers [7].

A very important application of natural products is associated with the production of biofuels. An anticipated shortage of fossil fuels, the increased demand for energy due to global growth, and concern for environmental issues and global warming have led countries to seek alternative and renewable energy sources, of which ethanol and biodiesel have attracted attention as biofuels. About $45 \%$ of the energy and $18 \%$ of the fuel consumed in Brazil is renewable. Elsewhere in the world, only $14 \%$ of the energy comes from renewable energy sources [20].

Biodiesel is a fuel derived from vegetable oils and animal fats. In Brazil, they can be produced from different oilseed species including castor oil, palm oil, canola, sunflower, peanut, soybean and cotton, and raw materials of animal origin such as bovine fat and swine fat (Table 1) [21].

On the order hand, alcohol can be produced from diverse lignocellulosic plant sources like sugarcane, maize, cassava, and beets [20], and Brazil is the world leader in producing ethanol from sugarcane with the 2012/2013 harvest resulting in $23,470,000 \mathrm{~m}^{3}$ of ethanol [22].

Once extracted, the raw material for biofuel production and electric power generation and the chemicals developed from by-products and residues from biomass are those with the greatest potential to add value to supply chains. The capacity to add value is due to the chemical industry which provide, in addition to supplies, final products for diverse sectors of the economy such as pharmaceutical, automotive, civil engineering, petrochemical, etc., as will be described later.

\section{Biomass by-products and residue applications}

After extraction of natural products of pharmaceutical interest or industrial application, such as polymers, or even of metabolites for biofuels, the residues (e.g., fibers [10]) or other compounds (e.g., nutrients [8]) are typically discarded, generating environmental pollution with an unreasonable loss of biomass that could be used for the production of different high-value products.

Similarly, residual biomass from agricultural activity can be converted into a variety of industrial materials, and a wide range of bioactive natural products can be recovered through different biological and chemical processes for extraction.

An example is apple pomace, which can be used as substrate for the microbial production of some organic acids (citric and lactic acids), enzymes (cellulases, amylases, and others), biofuels, and biopolymers as well as for the direct extraction of antioxidant compounds, such as catechins, quercetin glycosides, procyanidins, and caffeic and chlorogenic acids, among others [8]. In some studies, Aliakbarian [23] described the use of olive pomace in direct combustion, animal feed, and soil conditioning. Since only $2 \%$ of phenolic compounds are transferred to the oil and $98 \%$ are retained in the cake, olive pomace has been considered to be a potential source of these compounds.

The concern about the indiscriminate use of chemicals to control pests in various crops has encouraged the search for powerful insecticides of natural origin, but with reduced toxic effects on man, animals, and the environment. A product widely studied for this purpose is pyroligneous extract, an organically based by-product resulting from the condensation of smoke generated in the pyrolysis of wood, in particular for the production of vegetal charcoal. It is comprised of water, phenolic compounds, aldehydes, and organic acids [24]. Generally, this product is discarded in the process and released into the environment; however, studies have shown that it has a toning effect for plants in addition to presenting nematicide, fungicide, and insecticide action [24] in addition to its use as a preservative in cosmetic and sanitation products [25]. Pyroligneous extract is already produced and marketed in some regions of Brazil as Biopirol $^{\bullet}[26]$.

There is currently a growing interest in the development of natural additives for use in sunscreens and the option of new active filters involving the capability of ultraviolet light absorption and antioxidant activity.

Table 1 Raw materials used in the biodiesel production (B100) in Brazil (2008 to 2012) [21]

\begin{tabular}{lccccc}
\hline Raw materials & \multicolumn{4}{c}{ Volume $\left(\mathbf{m}^{\mathbf{3}}\right) /$ year } \\
\cline { 2 - 5 } & $\mathbf{2 0 0 8}$ & $\mathbf{2 0 0 9}$ & $\mathbf{2 0 1 0}$ & $\mathbf{2 0 1 1}$ & $\mathbf{2 0 1 2}$ \\
\hline Total & $1,177,638$ & $1,614,834$ & $2,387,639$ & $2,672,771$ & $2,719,897$ \\
Soybean oil & 967,326 & $1,250,590$ & $1,980,346$ & $2,171,113$ & $2,105,334$ \\
Cottonseed oil $_{\text {Animal fat }}^{\text {a }}$ & 24,109 & 70,616 & 57,054 & 98,230 & 116,736 \\
Other fatty materials $^{\text {b }}$ & 154,548 & 255,766 & 302,459 & 358,686 & 458,022 \\
\hline
\end{tabular}

Includes beef fat, chicken fat and p'ig fat. ${ }^{b}$ Includes palm oil, peanut oil, oilseed rape-oil, sunflower oil, castor oil, sesame oil, frying oil, and other fatty materials. 
Cashew nuts, one of the major exports from the Brazilian northeast, having exported 51,000 tons in 2007, is sometimes wasted by industry. The liquid extracted from cashew nut shells (CNSL) - 19,000 tons exported in 2007 - has been studied as additives to sunscreens [12]. Other applications of CNSL are described for paints, varnishes, resins, insecticides, fungicides, electrical materials, insulators, and adhesives [27].

The cashew tree is one good example of Brazilian biomasses which everything is availed. The wood, which is water resistant, is used in marine and civil engineering. Leaf or bark tea from this tree is still widely used throughout the Amazon rainforest as an effective medicine against diarrhea and colic. Leaves have healing power when used on wounds, and the nuts can be used in the preparation of pastries and chestnut flour [27].

The demand for oils and fats for edible purposes, biofuels and oleochemicals require feedstock with high-lipid productivity. Among some Brazilian native species, the macauba and the carnauba are distinctive. The residual biomass post-oil extraction has been widely investigated for the extraction of by-products or the direct application in some sectors, such as food or agronomic, aiming to increase the added value of these residues. The residue of carnauba leaves, after wax extraction, is rich in lignocellulosic material and is used as an organic fertilizer. The cake resulting from the extraction of macauba oil can be incorporated into animal feed, and due to a composition rich in fibers and sugars, it can also be used for human consumption. Natural dyes can be extracted from macauba oil including beta-carotene and phospholipids, which can be used in the manufacture of food and medicines [28].

Cassava, a potential source of carbohydrates, is a native biomass of the Brazilian territory. During processing, flour, starch, and liquid and solid wastes of negative environmental impact can be obtained. The liquid effluent is rich in water, starch, fiber, minerals, and cyanogen compounds, which can be exploited in different ways. Linamarin, for example, can be used in the treatment of tumor cells [28] from cyanogen derivatives.

Products of marine origin are one the most important classes of natural products that have interesting properties and industrial uses. The large quantities of by-products generated have great potential for becoming value-added compounds, such as lipids, proteins, amino acids and enzymes, which can be extracted from wastewaters and from solid residues (head, viscera, skin, tails and flesh) that are leftovers during the canning process. In some cases, these by-products are economically more attractive than the starting material [9].

\section{Conclusions}

Considering the diverse fauna and flora in Brazil, the possibility of obtaining compounds, whether biological or industrial interest, residues, and by-products derived from diverse biomasses must be continuously investigated in order to add value to the entire supply chain of potential natural products in and thus avoid possible problems of environmental impact that could result in disposing of these in nature.

Residues and by-products from plants, animals, and microorganisms are a valuable stock material to be used in a wide range of sectors, including bioenergy, fertilizers, food, feed, biomaterials (textiles, adhesives), or other fields. The reduction of environmental impact and generation of a new economy based on added value compounds will promote the sustainability.

Research should be continually encouraged to successfully achieve such aims so we can take maximum advantage of what nature can offer in a sustainable way that is beneficial in and of itself.

\section{Competing interests}

The authors declare that they have no competing interests.

\section{Authors' contributions}

The review presented here was carried out in collaboration between both authors. CMR defined the review theme; VCS and CMR wrote, read and approved the final manuscript.

\section{Author details}

${ }^{1}$ Institute of Chemistry, University of Brasília, CP 4478, 70910-970 Brasília, DF, Brazil. Embrapa Agroenergy - Parque Estação Biológica (PqEB), s/no, W3 Norte, 70770-901 Brasília, DF, Brazil.

Received: 1 April 2014 Accepted: 14 August 2014

Published online: 17 September 2014

\section{References}

1. Ministério do Meio Ambiente (2011) Quarto Relatório Nacional Para a Convenção Sobre Diversidade Biológica - Brasil. MMA, Brasilia. http://www. mma.gov.br/estruturas/sbf2008_dcbio/_arquivos/quarto_relatorio_147.pdf.

2. Cragg GM, Newman DJ (2013) Natural products: a continuing source of novel drug leads. Biochim Biophys Acta 1830:3670-3695

3. Bolzani VS, Valli M, Pivatto M, Viegas C, Jr (2012) Natural products from Brazilian biodiversity as a source of new models for medicinal chemistry. Pure Appl Chem 84(Suppl 9):1837-1846

4. Islam S, Shahid M, Mohammad F (2013) Perspectives for natural product based agents derived from industrial plants in textile applications - a review. J Clean Prod 57:2-18

5. Bellotti N, Amo B, Romagnoli R (2012) Tara tannin a natural product with antifouling coating application. Prog Org Coat 74:411-417

6. Santoni I, Pizzo B (2013) Evaluation of alternative vegetable proteins as wood adhesives. Ind Crops Prod 45:148-154

7. Sharma V, Kundu PP (2008) Condensation polymers from natural oils. Prog Polym Sci 33:1199-1215

8. Dhillon GS, Kaur S, Brar SK (2013) Perspective of apple processing wastes as low-cost substrates for bioproduction of high value products: a review. Renew Sust Energ Rev 27:789-805

9. Ferraro V, Carvalho AP, Piccirillo C, Santos MM, Castro PML, Pintado ME (2013) Extraction of high added value biological compounds from sardine, sardine-type fish and mackerel canning residues-a review. Mater Sci Eng C 33:3111-3120

10. Costa SM, Mazzola PG, Silva JCAR, Pahl R, Pessoa A, Jr, Costa SA (2013) Use of sugar cane straw as a source of cellulose for textile fiber production. Ind Crop Prod 42:189-194

11. Santana-Méridas O, Gonzales-Coloma A, Sanchez-Vioque R (2012) Agricultural residues as a source of bioactive natural products. Phytochem Rev 11:447-466

12. Romeiro LAS, Silva VC, Murta MM, Magalhães GC, Logrado LPL, Santos ML, Resck IS, Moura EA, Dellamora-Ortiz GM, Leitão AAC, Silva CS, Freitas ZMF, 
Santos EP (2006) Compounds Capable of Absorbing Ultraviolet Radiation, Compositions Containing Them and Processes for Their Preparation. WO Pat. WO2006/042391 A2

13. Zuanazzi JAS, Mayorga P (2010) Fitoprodutos e desenvolvimento econômico. Quim Nova 33(Suppl 6):1421-1428

14. Viegas C, Jr, Bolzani VS, Furlan M, Barreiro EJ, Young MCM, Tomazela D, Eberlin MN (2004) Further Bioactive Piperidine alkaloids from the flowers and green fruits of Cassia spectabilis. J Nat Prod 67:908-910

15. Rosa LH, Vieira MLA, Cota BB, Johann S, Alves TMA, Zani CL, Rosa CA (2011) Endophytic fungi of tropical forests: a promising source of bioactive prototype molecules for the treatment of neglected diseases. In: Rundfeldt C (ed) Drug development - a case study based insight into modern strategies, volume 18. Intech, Croatia

16. Valli M, Santos RN, Figueira LD, Nakajima CH, Castro-Gamboa I, Andricopulo AD, Bolzani VS (2013) Development of a natural products database from the biodiversity of Brazil. J Nat Prod 76:439-444

17. Ghaffar SH, Fan M (2014) Lignin in straw and its applications as an adhesive. Int J Adhes Adhes 48:92-101

18. Mosiewicki MA, Aranguren MI (2013) A short review on novel biocomposites based on plant oil precursors. Eur Polym J 49:1243-1256

19. Espinosa LM, Meier MAR (2011) Plant oils: the perfect renewable resource for polymer science?! Eur Polym J 47:837-852

20. Agência Nacional do Petróleo, Gás Natural e Biocombustíveis (2010) Biocombustíveis. ANP. http://www.anp.gov.br/?.pg=60467\&m=\&t1 =\&t2= $\& \mathrm{t} 3=\& \mathrm{t} 4=\& \mathrm{ar}=\& \mathrm{ps}=\& \mathrm{cachebust}=1409662524114$.

21. Produção de Biocombustíveis. http://www.petrobras.com.br/pt/nossasatividades/areas-de-atuacao/producao-de-biocombustiveis/. Accessed 14 July 2014

22. Ministério da Agricultura, Pecuária e Abastecimento (2014) Produção Brasileira de Cana-de-açúcar, Açúcar e Etanol. MAPA. http://www.agricultura. gov.br/arq_editor/file/Desenvolvimento_Sustentavel/Agroenergia/estatisticas/ producao/JULHO_2014/07_\%20prod_cana_acucar_etanol(3).pdf

23. Aliakbarian B, Casazza AA, Perego P (2011) Valorization of olive oil solid waste using high pressure-high temperature reactor. Food Chem 128:704-710

24. Souza-Silva A, Zanetti R, Carvalho GA, Mendonça LA (2006) Qualidade de mudas de eucalipto tratadas com extrato pirolenhoso. Cerne 12(Suppl 1):19-26

25. Almeida RSR (2012) Potencial do Extrato Pirolenhoso da Madeira de Eucalipto Como Agente Conservante de Cosméticos e Saneantes. PhD Thesis, Escola Superior de Agricultura "Luis de Queiroz"

26. Biopirol. www.biocarbo.com/. Accessed 14 July 2014

27. Mazzetto SE, Lomonaco D, Mele G (2009) Óleo da castanha de caju: oportunidades e desafios no contexto do desenvolvimento e sustentabilidade industrial. Quim Nova 32(Suppl 3):732-741

28. Favaro SP, Miranda CHB (2013) Aproveitamento de Espécies Nativas e Seus Coprodutos no Contexto de Biorrefinaria. Documentos, Embrapa Agroenergia

doi:10.1186/s40538-014-0014-0

Cite this article as: da Silva and Rodrigues: Natural products: an extraordinary source of value-added compounds from diverse biomasses in Brazil. Chemical and Biological Technologies in Agriculture 2014 1:14.

\section{Submit your manuscript to a SpringerOpen ${ }^{\odot}$ journal and benefit from:}

- Convenient online submission

- Rigorous peer review

- Immediate publication on acceptance

- Open access: articles freely available online

- High visibility within the field

- Retaining the copyright to your article

Submit your next manuscript at $>$ springeropen.com 